\title{
Negative-positive Security and the United States
}

\author{
Mohammad Agus Yusoff ${ }^{1} \&$ Fakhreddin Soltani $^{1}$ \\ ${ }^{1}$ School of History, Politics, and Strategic Studies (SOHPASS), Faculty of Social Sciences and Humanities, \\ Universiti Kebangsaan Malaysia, Bangi, Malaysia \\ Correspondence: Fakhreddin Soltani, School of History, Politics, and Strategic Studies (SOHPASS), Faculty of \\ Social Sciences and Humanities, Universiti Kebangsaan Malaysia, 43600 UKM, Bangi, Selangor, Malaysia. \\ E-mail: fakhreddinsoltany@gmail.com
}

\author{
Received: August 27, 2012 Accepted: September 20, 2012 Online Published: November 30, 2012 \\ doi:10.5539/ass.v8n15p244 \\ URL: http://dx.doi.org/10.5539/ass.v8n15p244
}

\begin{abstract}
The traditional approach to security is rooted in a strategy of balance of power among great powers and hence national security was based on situational interpretation of the concept among the great powers. Two negative and positive approaches have been used by states to interpret the concept of domestic security and national security. During the Cold War, the USA and the USSR applied negative approaches, and by generalizing the interpretation of their national interests to their spheres of influence, internationalized the concept. In other words, their security was not limited to national borders, and survival was defined in more vast manner. By the end of the Cold War, a positive approach was undertaken by the United States through emphasizing the democratic peace theory. The events of September $11^{\text {th }}, 2001$, showed that new forms of challenges such as terrorism have replaced traditional threats to security. To manage the crises sprung out of new challenges, they needed a different kind of approach. This article will explain the security approaches which were applied by the United States during three periods; the Cold War, post-Cold War, and after the events of September $11^{\text {th }}$.
\end{abstract}

Keywords: positive/negative security, Cold War, post Cold War, September $11^{\text {th }}$

\section{Introduction}

Since 1950, a variety of definitions for national security have been provided; For example, some scholars such as Buzan, Waever, and Wild referred to political, economic, societal, and environmental issues (1998) as security threats, while others such as Wheeler and Booth thought in terms of the reflective approach and referred to security as a process of emancipation (1992). Wolfers' definition, among a variety of definitions, was agreed on by scholars (Baylis 2001). He defined security as a lack of threat and fear against the values of a nation (Wolfers 1952).

There are two interpretations on the concept of security, including positive and negative ones. Realists emphasize a negative interpretation in which security refers only to a lack of direct militaristic threat against the country and the protection of citizens against an external enemy. The negative interpretation of security is the basis of the traditional approach on the concept (Carr 1946; Morgenthau 1972; Waltz 1979). Negative interpretation of the concept of security was dominant until the end of the Cold War. Before the Cold War began, states took care of their own security, and utilizing strategies such as balance of power were to serve as self-preservation. During the Cold war, super-powers defined their security based on the external enemy and their capability of threatening survival. During these periods, the USA and USSR, by generalizing the interpretation of their national interests to their spheres of influence, internationalized the concept. In other words, their security was not limited to national borders and survival was defined in a broader way. Particularly, security and the survival of allies were supposed as security and survival of their own.

The positive approach to the concept of security put one step forward, and beside lack of threat, added the concept of citizens' welfare to the security of the countries (Nye 2004). Positive interpretation dominated during the period between the end of the Cold War and the events of 9/11. During this era, great powers- especially the United States- paid more attention to their domestic issues, and promoting the welfare of citizens became the priority interest of the states to increase the security of the country. Some mentioned the end of history and arising of internal conflicts in victorious ideology out of the Cold War (Fukuyama 1992), while others emphasized the clash of civilizations (Hantington 1993) instead of states or some believed in beginning of 
dialogue among civilizations (Khatami 2000). But what was clear, was the rising of ethnic conflicts such as Bosnia, Chechnya.

The events of $9 / 11$ were a turning point that changed the nature of security and its interpretations, especially for the United States. Neither a negative interpretation nor a positive one was able to deal with it. The security of the states was threatened this time not by another country, which was the basis of the negative approach, nor by economic prosperity of other states, but by a new enemy called terrorism. The States could not provide security for the citizens inside the country, as terrorism aimed inside territorial borders. In following, security approaches applied by United States during three periods of the Cold War, post- Cold War, and after the events of September $11^{\text {th }}$ are explained.

\section{Cold War}

The Cold War period is characterized by an ideological struggle between the USA and the USSR. In this rivalry, the USA was representative of democratic values while the USSR proclaimed peace and freedom. Besides ideological differences, a number of reasons caused the Cold War- including the nuclear arms race, misinterpretations of each other's intentions, and overestimation of each other's capabilities (Dockrill and Hopkins 2006). The security of both sides was interpreted according to realist assumptions. In other words, both sides built up vast quantities of conventional and unconventional weapons. During this period, both the USA and the USSR committed themselves to their spheres of dominance in which the United States defined Western Hemisphere security as its own, and vice versa the USSR acted the same in the Eastern Hemisphere. During the Cold War, several proxy wars occurred in Africa, Latin America and Asia, because the two countries preferred to avoid direct conflict. Therefore, by generalizing the interpretation of their national interests to their spheres of influence and by using proxy wars, they internationalized their national security. Their security was not limited to national borders, and the definition of survival was broadened (Shinoda 2004). The idea of internationalizing the national security had its roots in the concept of collective security during the period between the two World Wars, in which national security of member states in the League of Nations was supposed as a common goal that the entire international society ought to respect. In other words, every state was responsible for the security of the others. This idea had a liberal basis, while during the Cold War it was interpreted according to realist assumptions. During the Cold war, two super-powers committed themselves to the security of the states in their spheres of dominance, because no states alone can provide national security-- but super-powers can, hence their national security is maintained by international systems of alliances (Shinoda 2004).

The United States used a variety of strategies to provide its security according to the internationalized approach. The Marshall plan (1947) was a symbol of this idea which was designed by General George C. Marshall, who was Harry Truman's Secretary of State, in order to promote the economic revival of Europe and in following, to bring it under the influence of the United States (Dockrill and Hopkins 2006). Therefore, the Marshall plan committed the United States for the reconstruction of Western Europe and prevented the expansion of USSR influence in it. According to the Marshal Plan, it was reported that the United States had allocated 13 billion US dollars to the countries of Western Europe in the period between 1948 and 1951(Hogan 2002; Agnew and Entrikin 2004; Mills 2008). The creation of the North Atlantic Treaty Organization (NATO) in 1949 was another sign of the United States' efforts to internationalize national security (Dockrill and Hopkins 2006). The division of Germany (1948-1949), the Korean War (1950-1953), and the Cuban missile crisis (1962) are some examples of the United States' internationalized interpretation on its security. Therefore, the United States interpreted its security according to the presence of a threat by the USSR, and this was the basis of the negative interpretation during Cold War.

\section{Post-cold War}

By the end of the Cold War, scholars speculated on the expected future of the international system and especially its effects on the security of the United States. Three main optimistic approaches: the obsolescence of war theory, economic liberalism, and the peace loving theory-democratic peace theory- (Mearshiemer 1990) had predicted future conditions of international politics based on different assumptions. Proponents of the obsolescence of war theory argued that in the new era, states have discovered the irrationality of entering into war, and as a result the future would be a peaceful one. Economic liberalists emphasized the logic of prosperity in states and argued that in the new era, states will see that war is counter to economic prosperity, and in following they will avoid the onset of war. And peace-loving democracy theorists believed that common democratic values among states would prevent them from fighting each other.

But realists had different ideas. They were pessimistic and argued that the post-Cold War era would be a more conflicted one because bipolarity had been the most peaceful situation among the states. For example, Kenneth 
Waltz argued that "with two great powers, balancing is done mainly by internal means. Allies have been useful and have therefore been wanted, but they were not essential in the security relations of the big two" (Waltz 1993) In other words, uncertainty is at its lowest level because calculations on how to balance the rival country are done internally and there is no need to rely on allies. In the same way, Mearsheimer argued that "the historical record shows a perfect correlation between bipolarity, equality of military power, and nuclear weapons, on the one hand, and the long peace, on the other hand. When an equal bipolarity arose and nuclear weapons appeared, peace broke out" (Mearshiemer 1990).

Democratic peace theory was the approach emphasized by George H. W. Bush following the Cold War, when he advocated the idea of a "New World Order" (Haley 2004). In his speech on 16 January 1991, he introduced the New World Order as a situation in which "the rule of law... governs the conduct of nations," and "in which a credible United Nations can use its peacekeeping role to fulfill the promise and vision of the UN's founders" (Bush 1991). The world was supposed to have one final goal to achieve, which was finding order in democratic values. During this period, domestic issues became the primary focus of the United States policy to provide security; because it was presumed that the spontaneous spread of democratic values would protect the security of the United States. In other words, a democratic victory at the end of the Cold War would spontaneously improve Pan-American perceptions of other people around the world. As then-president Bill Clinton stated, the United States could become strong in the international sphere if it was able to create a strong country in the United States (Clinton 1992).

George W. Bush did not make deep changes in Clinton's policies. He followed the same policies by declaring compassionate conservatism (Soltani and Jawan 2010) as a cornerstone of his administration. Compassionate conservatism is the policy of dealing with inequalities among citizens and generally in civil rights, but without direct government action. According to compassionate conservatism, the behavioral problems such as criminality, which have been caused by segregation and slavery in society, should be dealt as priorities (Teles 2009). The focuses of compassionate conservatism in the Bush administration were "health" and "retirement security" especially for low income citizens (Bush 2000). In his speech on 20 January 2001, he characterized the Cold War era as "chaos" and post-Cold War era as "civility" (Bush 2001). According to him, "cynicism" was a characteristic of the Cold War, and "trust" is a characteristic of the post-Cold War era. So, trusting in other countries was no longer risky regarding the survival of the United States; American values had won the war and were going to take root in many nations (Soltani and Jawan 2010). Therefore, the security of the United States was supposed to be provided through the spontaneous management of perceptions in other parts of the world.

So, the basis of the post-Cold War era security interpretation lay in the improvement of the welfare of citizens. The focus of presidential administrations was to improve the quality of life in society. This was the basis of the positive interpretation of the concept of security, in which it was supposed that democratic values were going to be embraced by other parts of the world and bring security for the United States. A domestically strong society is the pillar of security when applying the positive approach. In this approach, it was emphasized that democratic countries do not go to war with each other and do not threaten the security of each other (Doyle 1986).

\section{September 11}

The attack of September $11^{\text {th }}, 2001$ was the first such assault on US soil since the Japanese bombed Pearl Harbour on December $7^{\text {th }} 1941$ (White 1997). "Beginning" was the word George W. Bush used to describe the era after the events of September $11^{\text {th }}$ (Bush, 2002). What made this period different from others was the nature of the enemy; they could not be dealt with using traditional weapons. In other words, new threats did not arise from rival countries, but from weak states and groups that were not able to confront the United States directly. As the 2002 security strategy states, the September $11^{\text {th }}$ events showed that weak states could become as dangerous as stronger states (NSS 2002), and that geographic and military strengths of the US could no longer guarantee its security against these enemies and threats (QDR 2001). So the question now was how to provide security for the United States. Relying on soft power (Nye 2004) was a pillar of perception management to provide security. Although George W Bush insisted on realist strategies of preventive war and pre-emptive action rather than soft power, the main ideas of the soft power approach were clear in his speeches and security strategies. For example, in 2006 the security strategy stated that promoting democracy and the rule of law is the responsibility of the United States because it will facilitate the flow of correct information and in so doing, educate and inform people throughout the world on how to make correct decisions (NSS 2006). Therefore, accordingly, the security of the United States could best be provided through democratic values and familiarizing people with these values. Confronting individuals and groups that are organized in weak states was not possible by conventional approaches, so the only way was to change their perceptions towards the United States. 
A combination of both positive and negative interpretations on the concept of security can be traced in this period. The presence of a threat such as terrorists and rogue states were interpreted according to the negative approach to national security, while the positive approach was employed in democratizing the potential states that harbor terrorism. For example, on one hand, in the 2002 national security strategy, defining the security environment was based on a negative interpretation in which it was stated that:

"New deadly challenges have emerged from rogue states and terrorists. None of these contemporary threats rival the sheer destructive power that was arrayed against us by the Soviet Union. However, the nature and motivations of these new adversaries, their determination to obtain destructive powers hitherto available only to the world's strongest states, and the greater likelihood that they will use weapons of mass destruction against us, make today's security environment more complex and dangerous.... We must be prepared to stop rogue states and their terrorist clients before they are able to threaten or use weapons of mass destruction against the United States and our allies and friends....To contend with uncertainty and to meet the many security challenges we face... We must prepare for more such deployments by developing assets such as advanced remote sensing, long-range precision strike capabilities, and transformed maneuver and expeditionary forces. This broad portfolio of military capabilities must also include the ability to defend the homeland, conduct information operations, ensure U.S. access to distant theaters" (2002).

On the other hand, preparing a secure environment for the future of the United States was based on a positive interpretation of security in which it was stated that:

"America must stand firmly for the nonnegotiable demands of human dignity: the rule of law; limits on the absolute power of the state; free speech; freedom of worship; equal justice; respect for women; religious and ethnic tolerance; and respect for private property....[by] using the full influence of the United States, and working closely with allies and friends, to make clear that all acts of terrorism are illegitimate so that terrorism will be viewed in the same light as slavery, piracy, or genocide: behavior that no respectable government can condone or support and all must oppose....[and by] using effective public diplomacy to promote the free flow of information and ideas to kindle the hopes and aspirations of freedom of those in societies ruled by the sponsors of global terrorism" (2002).

Similar to George W. Bush, President Obama compared the attacks to war and stated that "our nation is at war, against a far-reaching network of violence and hatred" (Obama 2009). He emphasized that "Throughout our history, no issue has united this country more than our security...All of us are committed to its defense. So let's put aside the schoolyard taunts about who's tough. Let's reject the false choice between protecting our people and upholding our values. Let's leave behind the fear and division, and do what it takes to defend our nation and forge a more hopeful future...for America and for the world" (Obama 2010).

He followed the same policy as Bush's, but with more emphasis on international organizations, especially the U.N. and NATO. Both negative and positive interpretations on the concept of security can be found in the security strategy of 2010. The 2010 security strategy of the United States declares that:

"Military force, at times, may be necessary to defend our country and allies or to preserve broader peace and security, including by protecting civilians facing a grave humanitarian crisis....The United States must reserve the right to act unilaterally if necessary to defend our nation and our interests....While the use of force is sometimes necessary, we will exhaust other options before war whenever we can, and carefully weigh the costs and risks of action against the costs and risks of inaction. When force is necessary, we will continue to do so in a way that reflects our values and strengthens our legitimacy, and we will seek broad international support, working with such institutions as NATO and the U.N. Security Council" (2010).

And yet it also states:

“America's commitment to democracy, human rights, and the rule of law are essential sources of our strength and influence in the world.... These efforts to advance security and prosperity are enhanced by our support for certain values that are universal. Nations that respect human rights and democratic values are more successful and stronger partners, and individuals who enjoy such respect are more able to achieve their full potential....In keeping with the focus on the foundation of our strength and influence, we are promoting universal values abroad by living them at home, and will not seek to impose these values through force. Instead, we are working to strengthen international norms on behalf of human rights, while welcoming all peaceful democratic movements" (2010). 
Therefore, a combination of negative and positive approaches to national security has been followed by the United States in order to deal with threats since September 11th 2001. It can be contemplated that there were no extreme differences between the administrations of George W. Bush and Barack Obama when it came to handling national security. In other words, they have both emphasized the importance of military strength in the United States, while simultaneously focusing on democratic values to create a more secure environment.

\section{Conclusion}

Since the beginning of the Cold War, the United States has experienced three different eras in which different approaches to national security were applied. The application of the approaches was based on how the US interpreted its security. Two interpretations were provided: negative and positive. The negative position is based on a realist approach in which security can best be provided through a balance of power among great powers. In other words, feelings of fear can be mitigated through equalities among the rival powers, although the concept of equality is defined variously. The negative approach was dominant during the Cold War. The positive approach to security was followed by the United States in the post-Cold War era. The positive approach was supported by three main optimistic ideas: the obsolescence of war theory, economic liberalism, and the democratic peace theory. Among them, the democratic peace theory was the one the United States emphasized. According to this rationale, democracies do not fight each other; therefore, it was argued that the feeling of fear is at its lowest level because there is no serious rival for the US, and the spontaneous spreading of democratic values protects the US. The events of September 11th 2011 showed that none of the mentioned approaches is enough to be the basis for providing security. The combination of negative and positive interpretations was applied simultaneously, showing that the spreading of democratic values has been the dominant approach, while realist strategies were applied to support it.

\section{References}

Agnew, J., \& Entrikin, J. N. (2004). The Marshall Plan today: model and metapho. Londan and New York, Routledge. http://dx.doi.org/10.4324/9780203503072

Baylis, J. (2001). International and Global Security in Post-Cold War Era. In J. Baylis, \& S. Smit (Eds.), The Globalization of World Politics: An Introdoction to International Relations. New York, Oxford University Press.

Bush, G. H. W. (1991). Address to the Nation on the Invasion of Iraq. Retrieved May 10, 2012, from http://millercenter.org/president/speeches/detail/3428

Bush, G. W. (2000, August 3). President George W. Bush's Accepts Republican Party Nomination. Retrieved August 23, 2009, from http://www.australianpolitics.com/news/2000/00-08-03a.shtml

Bush, G. W. (2001, January 20). President George W. Bush's Inaugural Address. Retrieved March 25, 2009, from http://www.johnstonsarchive.net/policy/bushinaug.html

Bush, G. W. (2002, January 29). President George W. Bush's State of the Union Address. Retrieved March 13, 2012, from http://www.johnstonsarchive.net/policy/bushstun2002.html

Buzan et al. (1998). Security: A New Framework for Analysis. Colorado, Lynne Rienner.

Carr, E. H. (1946). The Twenty Years Crisis. Londan, Macmillan.

Clinton, B. (1992, July 16). A Vision for America: A New Covenant. Retrieved February 25, 2009, from http://www.skepticfiles.org/conspire/acceptcl.htm

Clinton, B. (1992, July 16). Acceptance Speech to the Democratic National Convention. Retrieved from http://www.4president.org/speeches/billclinton1992acceptance.htm

Defenselink. (2001, September 30). Quadrennial Defense Review Report. Retrieved September 28, 2009, from http://www.defenselink.mil/pubs/pdfs/qdr2001.pdf

Dockrill, M. L., \& Hopkins, M. F. (2006). The Cold War, 1945-1991. London, Palgrave Macmillan.

Doyle, M. W. (1986, December). Liberalism and World Politics. The American Political Science Review, 80(4), 1151-1169. http://dx.doi.org/10.2307/1960861

Fukuyama, F. (1992). The End of History and the Last Man. London, Hamish Hamilton.

Globalsecurity. (2006). The National Security Strategy of the United States of America. Retrieved September 28, 2009, from http://www.globalsecurity.org/military/library/policy/national/nss-060316.htm

Haley, P. E. (2004, April). A Defensive Grand Strategy for the United States. Armed Forces \& Society, 30, 20. 
Hantington, S. P. (1993). The Clash of Civilizations? Foreign Affairs, 72(3), 28. http://dx.doi.org/10.1177/0095327X0403000307

Hogan, M. J. (2002). The Marshal Plan. New York, Cambridge University Press.

Khatami, M. (2000). Dialogue among Civilizations. Retrieved May 2, 2012, from http://www.unesco.org/dialogue/en/khatami.htm

Mearshiemer, J. (1990). Back to the future: Instability in Europe after the Cold War. International security, 15(1), 52.

Mills, N. (2008). Winning the peace: the Marshall Plan and America's Coming of Age as a Super Power. New York, Palgrave.

Morgenthau, H. J. (1972). Politics among nations: the struggle for power and peace. New York, Alfred Knopf.

NDU. (2002). The National Security Strategy of the United States of America. Retrieved September 28, 2009, from http://www.ndu.edu/library/epubs/nss09-2002.pdf

NDU. (2002). The National Security Strategy. Retrieved September 28, 2009, from http://www.ndu.edu/library/epubs/nss09-2002.pdf.

Nye, J. S. (2004). Power in the Global Information Age (From realism to globalization). New York, Routledge.

Obama, B. (2009). Inaugural address. Retrieved April 28, 2012, from http://www.whitehouse.gov/blog/inaugural-address

Obama, B. H. (2010). State of Union. Retrieved May 25, 2012, from http://www.huffingtonpost.com/2010/01/27/state-of-the-union-2010-full-text-transcript_n_439459.html

Shinoda, H. (2004). The Concept of Human Security: Historical and Theoretical Implications. Retrieved May 10, 2012, from http://home.hiroshima-u.ac.jp/heiwa/Pub/E19/chap1.pdf

Soltani, F., \& Jawan, J. A. (2010). Compassionate Conservatism VS Bush Doctrine. Cross-cultural Communication, 6(3), 17.

Teles, S. M. (2009, Fall). The Eternal Return of Compassionate Conservatism. National Affairs, (1), 20.

Waltz, K. (1979). Theory of International Politics. New York, Random House.

Waltz, K. N. (1993). The Emerging Structure of International Politics. International Security, 18(2), 44-79. http://dx.doi.org/10.2307/2539097

Wheeler, N. J., \& Booth, K. (1992). The Security Dilemma. In J. Baylis, \& N. J. Rengger (Eds.), Dilemmas of World Politics: International Issues in a Changing World. Oxford, Clarendon Press.

White, G. M. (1997, March). Mythic History and National Memory: The Pearl Harbor Anniversary. Culture and Psychology, 3, 16. http://dx.doi.org/10.1177/1354067X9700300104

Whitehouse. (2010). National Security Strategy. Retrieved April 28, 2012, from http://www.whitehouse.gov/blog/inaugural-address.

Wolfers, A. (1952). National Security as an Ambiguous Symbol. Political Science Quarterly, 67(4), 22. http://dx.doi.org/10.2307/2145138 